ESJ Social Sciences

\title{
Moderating Effect of Business Environment on the Relationship Between Foreign Direct Investment and Local Firm's Performance
}

\author{
Wanjere M. D. \\ PhD Candidate, University of Nairobi, Kenya \\ Kinoti $M$. \\ Irai $X . N$. \\ Ogutu M. \\ School of Business, University of Nairobi, Kenya
}

Doi:10.19044/esj.2021.v17n27p131

Submitted: 12 April 2021

Accepted: 21 June 2021

Published: 31 August 2021
Copyright 2021 Author(s)

Under Creative Commons BY-NC-ND

4.0 OPEN ACCESS

Cite As:

Wanjere M.D., Kinoti M., Irai X.N. \& Ogutu M. (2021). Moderating Effect of Business Environment on the Relationship Between Foreign Direct Investment and Local Firm's Performance. European Scientific Journal, ESJ, 17 (27), 131.

https://doi.org/10.19044/esj.2021.v17n27p131

\begin{abstract}
This paper focuses on investigating the moderating role of business environment on the relationship between FDI and the performance of manufacturing firms in Kenya. Little information is documented on the role of business environment on the relationship between FDI and the performance of firms. The study population comprised of 100 companies registered with KAM as at the time of data collection in 2019 , with 10 percent or more foreign ownership. The research used a structured questionnaire to collect primary data. To analyze data, descriptive and inferential statistics was used. The results revealed that there was a statistically significant moderating effect on the relationship between FDI and firm performance. This implies that an incremental change in the interaction between FDI and business environment would generate growth in company's performance. In Kenya and other SubSahara African countries, the government needs to come up with polices geared towards improving their business environment to spur the growth of the key sectors of the economy.
\end{abstract}


Keywords: Foreign Direct Investment, Business Environment, Firm Performance

\section{Introduction}

The concept of a business environment is widely studied by scholars in the field of business. Early organization theorists conceptualized the business environment based on uncertainty, resource dependence, efficiency, and ecology, which are the four main perspectives (Thompson, 1967). Dethier, Hirn, and Straub (2010) posited that a business environment is a setting built to facilitate day-to-day business operations and include the physical structures, financial accessibility, safety, and regulatory frameworks. The study of Rocha (2012) (cited in Brașoveanu and EvelinaBălu, 2014) suggested that simplified business environments supported by budgetary and fiscal policies were able to enhance the emergence of local firms.

Khondoker and Kaliappa (2010) observed that a small number of developing nations across the world draws large substantial amount of foreign direct investment by creating business friendly environment and implementing more external trade-oriented policy. Muhammad and Kashif (2013) noted that government policies that facilitate training encourage MNEs to invest in human resource development of the host countries. This minimizes financial constraints and market failures and can help the host economy benefit from FDI. The empirical results of World Bank (2017) support the relationship between business environments and various aspects of firm performance. The study of Hallward-Driemeier and Mengistae (2005) (cited in Hodud, Madline, Faridah, Shamshubarida and Mohd, 2014) identified infrastructure as an influential factor in firm growth. They identified power outages and custom delays as some of the factors that affect a firm's performance negatively.

Foreign investors are attracted by conducive business environment with profitable opportunities and low risks (Hodud et al., 2014). Also, financial constraints in particular cost and access to finance has been recognized as an obstacle to firms' development, particularly in developing markets (Sprenger \& Lazarevaa, 2016). Kamran, Chor, and Manova (2016) claim that countries that have good financial markets normally attract more MNCs than their counterparts with undeveloped financial markets.

The goal of the Kenyan Government is to ensure that manufacturing industry increases its contribution to national economy by about 15 percent of the GDP in 2022 (KAM, 2018). This can be realized if the level of investment is increased in this sector and the necessary skills and technologies to drive the sector are also made available. However, the level of investment realized in this sector is still very low and credit to the sector declined by 4.6 to Ksh 277.4 billion in 2016 and Ksh 290.9 billion in 2015 (KNBS, 2017). Other measures to spur growth will involve refining Kenya's industrial policy to 
foster globally competitive companies, promoting exports and global competitiveness, instituting rapid sector-focused FDI attraction, and creating industrial zones and parks to promote manufacturing industries.

The focus of the paper is to examine the moderating role of business environment on the relationship between foreign direct investment and performance of Kenyan manufacturing firms. Despite the important role played by the business environment in facilitating FDI spillover, its role has not been systematically studied. Therefore, this makes the current study suitable. The study investigated whether business environment has significant moderating effect on the relationship between FDI and the performance of local manufacturing firms.

\section{Literature Review}

\subsection{Foreign Direct Investment, Business Environment, and Firm Performance}

The impact of FDI on local economy has been empirically established to hinge on the business setting of the hosting country. Azman and Ahmad (2010) (cited in Edrees, 2015) noted that spillover may be considerably higher in a particular business environment such as better-quality infrastructure, quality human capital, and established financial markets. The study of HsiangFeng, Hsien-Bin, and Dja-Shin (2012) to determine if dynamism is a moderating factor concludes that external factors in a business setting affects the innovative activities of a firm. This is supported by Gui-Diby (2014) who explained that poor business environment results to negative association between FDI and stimulation of economic development.

Khondoker and Kaliappa (2010) further observe that the number of developing economies across the world receive significant amount of FDI by creating business friendly environment and embracing more external driven trade strategy. Furthermore, countries with friendly business environments, affordable skilled labour, electricity and energy, and good infrastructure tend to draw higher flow of FDI. The empirical results of World Bank (2017) support a strong relationship between business environments and various aspects of firm performance.

Acccording to Pradhan and Bagchi (2013), investment in the transport systems minimizes trading costs and consequently improves the competitive advantage of firms. The study of Alfao, Chanda, Oscan, and Sayek (cited in Muhammad and Kashif, 2013) found that foreign direct investment promoted growth about three times in countries that had well developed financial systems than their counterparts with poor financial systems. To support this claim, they explained that transfer of technology from MNEs differed among countries and depended upon cooperation among government, industry, academia, and labour. 
They further observed that foreign direct investment is more advantageous in a country that has created a sufficient pool of human capital and a minimum threshold of skills. Thus, the individual country context influences the probable gains of FDI for hosting countries and is therefore highly spatially variegated.

Foreign investors are attracted by conducive business environment with profitable opportunities and low risks (Hodud, Madline, Faridah, Shamshubarida \& Mohd, 2014). Kamran, Chor, and Manova (2016) claim that host countries that have good financial markets normally attract more MNCs than their counterparts with undeveloped financial markets.

Hsiang-Feng et al. (2012) suggested that the environment exerts a moderating impact on the link between innovativeness and firm performance. They established that the dynamic nature of environmental changes moderates the link between organizational performance and the decision-making processes. More so, the harsh environmental condition minimizes the innovativeness of a firm. The study carried out by Rocha (cited in Brașoveanu and EvelinaBălu, 2014) noted that an attractive business environment with appropriate budgetary policies supports the development of local firms. World Bank (2017) also opined that improving business regulatory environment is a way of facilitating investment in areas that are lagging behind. The study of Hallward-Driemeier, Wallsten, and Xu (cited in Hodud et al., 2014) further established that exploitive government regulations affected firm performance negatively and sales were likely to grow by 42.6 percent. However, employment was expected to grow by 46.7 percent when regulatory burdens were reduced by one (1) standard deviation.

Edrees (2015) studied the influence of business environment and foreign direct investment on economic development and established a negative association between FDI and economic development across lowincome and middle-income strata using variables such as human resource and infrastructure on the economic performance of Sub-Saharan countries. Bruno and Cipollina (2014) affirmed that the indirect implications of FDI are characterized by inconclusive results since they are dependent on the development status of the hosting economy.

The moderating influence of business environments and the effect of FDI on the performance of firms has not been explored in a coherent manner. In a different setting, Okeyo (2013) established that external business environmental changes had moderating implications on performance. Past studies have also revealed that the simultaneous consideration of organizations performance and business environment factor is likely to provide a richer understanding when examining firm's performance. Based on the literature provided in this section, the current study suggests that a business environment 
moderates the link between FDI and the performance outcomes of manufacturing companies.

\section{Conceptual Framework}

\subsection{Conceptual Framework}

Kombo and Tromp (2009) noted that conceptual framework denotes a set of broad thoughts and values extracted from relevant spheres of study, which are adapted in configuring a subsequent presentation. The conceptual framework was established on a diverse theoretical underpinning including FDI theories, dynamic capabilities, knowledge based and resource dependence to supplement the knowledge of FDI and associated variables.

Drawing from these theories, the study operationalized FDI as a multidimensional concept comprising of capital-flow, advanced production technology, marketing expertise, and management know-how. Thus, business environment moderates the link between FDI and firm performance and the framework is illustrated in Figure I.

Figure I. Conceptual Model

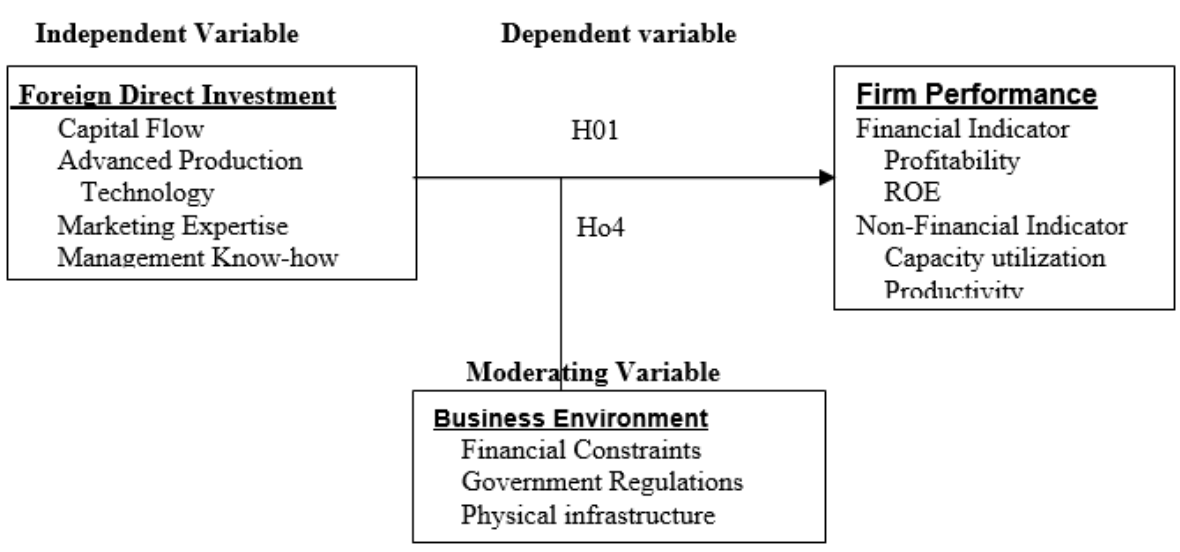

Source: Researcher 2017

\subsection{Conceptual Hypotheses}

The following hypotheses guided the study:

$\mathrm{H} 1$ : Business environment has no significant moderating effect on the relationship between FDIs and performance of manufacturing firms in Kenya.

\subsection{Variable Operationalization}

FDI was the independent variable of the study, and it was operationalized as capital flow, advanced production technology, marketing expertise, and management know-how. The moderating variable business environment was conceptualized as financial constraint, government regulations, and physical infrastructure. 
Firm performance was the dependent variable, and it was operationalized using financial and non-financial indicators of performance. Firm's performance was then assessed using two items of financial indicators of performance (profitability and ROE) and two items of non-financial indicators of performance (capacity utilization and employee's productivity) in order to establish output of the FDI variables.

\section{4. $\quad$ Methodology}

This research adopted a correlational design to evaluate relationship among variables. The study population consisted of all the 100 manufacturing firms registered with KAM, with over $10 \%$ foreign investment in Kenya. The firm was the principal unit under investigation.

The data was collected from a member of the top management preferably the CEO or the finance and strategy director. This is because they were considered knowledgeable about the issue under investigation. Thus, they were the main informants. Their choice is consistent with similar studies conducted by Shabarati, Jawad, and Bontis (2010) and Cabrita and Bontis (2008) who claim top managers are knowledgeable about organizational characteristics.

Both descriptive and inferential statistics were utilized to analyze the data. Descriptive statistics was computed to represent general information and firm characteristics (Kothari, 2014). Additionally, a series of regression analysis was conducted to assess the relationship between the independent and dependent variables so as to determine whether the results are significant or not. Table I provides a summary of the hypothesis test and analytical procedures.

Table I. Objectives, Hypotheses, Tests, and Analytical Models

\begin{tabular}{|c|c|c|c|}
\hline Objective & Hypothesis & Hypothesis Test & Analytical Model \\
\hline $\begin{array}{l}\text { Objective 1: } \\
\text { Determine the } \\
\text { moderating rol } \\
\text { of business } \\
\text { environment on } \\
\text { the } \\
\text { relationship } \\
\text { between FDI } \\
\text { and firm } \\
\text { performance. }\end{array}$ & $\begin{array}{l}\text { H1: Business } \\
\text { environment } \\
\text { has no } \\
\text { significant } \\
\text { moderating } \\
\text { effect on the } \\
\text { relationship } \\
\text { between FDI } \\
\text { and firm } \\
\text { performance. }\end{array}$ & $\begin{array}{l}\text { Regression analysis (process } \\
\text { analysis method) as suggested by } \\
\text { Baron \& Kenny }(1986) . \\
\text { Step 1: FP }=\beta 0+\beta 1 \mathrm{FDI}+\varepsilon \\
\text { Step2: } \mathrm{FP}=\beta 0+(\beta 1 \mathrm{FDI})+(\beta 2 \mathrm{BE})+ \\
\varepsilon \\
\text { Where } \beta 0=\text { Constant } \\
\beta 1, \beta 2,=\text { Regression coefficient } \\
\mathrm{FP}=\text { Firm's performance } \\
\mathrm{FDI}=\text { composite index of Foreign } \\
\text { Direct Investment } \\
\mathrm{BE}=\text { composite index of Business } \\
\text { Environment } \\
\text { composite* }=\text { interaction term } \\
\varepsilon=\text { Error term }\end{array}$ & $\begin{array}{l}\mathrm{R}^{2} \text { determines variation in th } \\
\text { dependent variable that is accounte } \\
\text { for by independent variables. } \\
\text { significant change in adjusted } \mathrm{R}^{2} \mathrm{o} \\
\text { the interaction of moderatin } \\
\text { variable confirms moderatin } \\
\text { effect. } \\
\text { F- test evaluates the general } \\
\text { significance of a model. } \\
\text { Beta }(\beta) \text { expresses contribution o } \\
\text { individual independent variables t } \\
\text { model's significance. } \\
\text { P-value, which in this case will } \\
0.05 \text {, evaluates whether step } 11 \text { to } \\
\text { are statistically significant. }\end{array}$ \\
\hline
\end{tabular}




\section{Preliminary Analysis}

\subsection{Descriptive Statistics}

Descriptive statistics were useful in this study since they presented quantitative descriptions in a manageable form. The findings are presented in the preceding section.

\subsubsection{Foreign Direct Investment}

In this study, FDI was conceptualized using four variables namely: capital flow, advanced production technology, marketing expertise, and management know-how (Muhammad \& Kashif, 2013; Leman \& Ismet, 2015). The respondents were required to provide answers by indicating if FDI introduction led to certain activities associated with the capital flow, advanced production technology, marketing expertise, and management know-how in their organizations. The findings are presented in Table II in the subsequent subsections.

Table II. Foreign Direct Investment

\begin{tabular}{|c|c|c|c|c|c|}
\hline \multirow[b]{2}{*}{ VARIABLE } & \multirow[b]{2}{*}{$\mathbf{N}$} & \multicolumn{3}{|c|}{ STD. } & \multirow[b]{2}{*}{$\mathbf{C V}$} \\
\hline & & MEAN & DEVIATIO: & VARIANCE & \\
\hline pital Flow & 75 & 2.68 & 0.70 & 0.49 & 0.26 \\
\hline $\begin{array}{l}\text { Advanced productio } \\
\text { Technology }\end{array}$ & 75 & 2.31 & 0.86 & 0.75 & 0.38 \\
\hline ırketing Expertise & 75 & 2.43 & 0.86 & 0.76 & 0.31 \\
\hline $\begin{array}{l}\text { inagement } \\
\text { ow-how }\end{array}$ & 75 & 2.46 & 0.86 & 0.74 & 0.30 \\
\hline erall FDI & 75 & 2.47 & 0.82 & 0.685 & 0.3125 \\
\hline
\end{tabular}

The overall ranking for FDI had a mean score of 2.47, standard deviation of 0.82 , variance of 0.68 , and $\mathrm{CV}$ of 0.3125 . The highest ranked variable was capital flow with mean score above 2.68 , standard deviation of 0.70 , Variance of 0.49 , and CV of 0.026 . This was followed by management knowhow with mean score above 2.46, standard deviation of 0.86 , Variance of 0.7 , and CV of 0.30. Subsequently, marketing expertise had mean score above 2.43, standard deviation of 0.86 , Variance of 0.7 , and $\mathrm{CV}$ of 0.31 . Finally, advanced production technology had mean score of above 2.31, standard deviation of 0.86 , Variance of 0.7 , and CV of 0.38 . This affirms the earlier assertion by Temiz and Aytac (2014), Asuantri and Yasmin, (2017), and Leman and Ismet (2015) that FDI inflows enables developing countries to accumulate capital and close capital deficiencies.

\subsubsection{Business Environment}

Business environment was hypothesized to have a moderating influence on the link between FDI and manufacturing firm performance. Three 
variables were used to evaluate various aspects of the business environment, which was operationalized as financial access, government regulations, and physical infrastructure. The findings in Table III shows that the overall rating for business environment had a mean of 2.77, standard deviation of 1.30, variance of 1.70 , and a $\mathrm{CV}$ of 0.47 . The highest ranked variable of business environment was physical infrastructure with a mean of 2.93. This was followed by financial access, which had mean score of 2.71. Subsequently, government regulations also had mean score of 2.66. The results are presented in Table III below.

Table III. Business Environment

\begin{tabular}{lcccccc}
\hline Business Environment & $\mathrm{N}$ & Mean & Std. Dev & Variance & CV & \\
\hline ancial Access & 75 & 2.71 & 1.29 & 1.68 & 0.47 \\
Government regulations & 75 & 2.66 & 1.30 & 1.69 & 0.49 \\
Physical infrastructure & 75 & 2.93 & 1.31 & 1.72 & 0.46 \\
\hline Overall & $\mathbf{7 5}$ & $\mathbf{2 . 7 7}$ & $\mathbf{1 . 3 0}$ & $\mathbf{1 . 7 0}$ & $\mathbf{0 . 4 7}$ \\
\hline
\end{tabular}

\subsection{Diagnostic Test}

To proceed with regression analysis, it is necessary that the underlying regression model be checked for adequacy. The model must meet a series of conditions, which include normality and multicollinearity. Violation of these assumptions puts the researcher at the risk of producing misleading estimates (Brooks, 2008).

\subsubsection{Normality Tests}

The study used the histograms and Kolmogorov-Smirnov normality test to check for normality of the data. Miot (2017) posited that a good and decent data used in research is normally distributed. The results are displayed in Table IV.

Table IV. Normality Test statistics

\begin{tabular}{llll|lll}
\hline \multicolumn{5}{c}{ "Kolmogorov-Smirnov" } \\
& Statistic & df & Sig. & Statistic & df & Sig. \\
\hline FDICF & .273 & 75 & .000 & .771 & 75 & .000 \\
FDIAPT & .186 & 75 & .000 & .938 & 75 & .001 \\
FDIME & .175 & 75 & .000 & .890 & 75 & .000 \\
FDIMKH & .192 & 75 & .000 & .876 & 75 & .000 \\
BE & .110 & 75 & .024 & .967 & 75 & .049 \\
FP & .142 & 75 & .001 & .953 & 75 & .007 \\
\hline \multicolumn{7}{r}{}
\end{tabular}

A non-significant result of $\mathrm{p} \geq 0.05$ (at $5 \%$ significance level) implies a normal distribution. In this case, the sig. value is .000 for each variable. 
However, business environment had a significant value of 0.024 , while firm's performance had a significant value of 0.001 . This shows that this assumption of normality has been violated and it is common in large samples (Pallant, 2005).

The data was investigated further for normality using histogram graphs. The findings of the distribution of the scores were presented graphically as shown in the histograms presented in Figures II to IV.

\subsubsection{Histogram Graphs for Normality of Responses i) Foreign Direct Investment}

Figure II displays a symmetrical histogram, which is an indication that FDI was normally distributed. Specifically, the variable followed a normal distribution with a mean equal to 2.46 and standard deviation of 0.311 . Therefore, it was concluded that the foreign direct investment variable met the normality condition.

Figure II. Histogram of Foreign Direct Investment

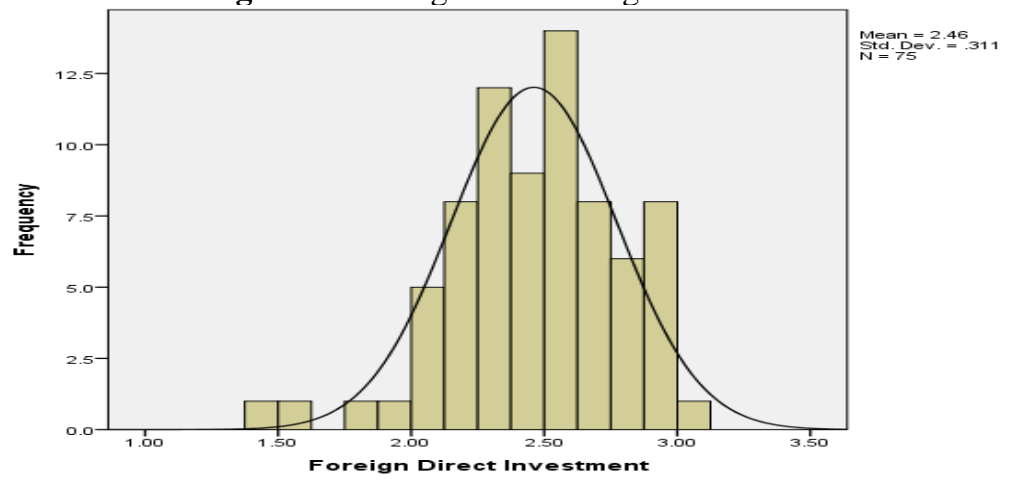

Source: Field Data 2019

\section{ii) Business Environment}

The business environment variable was also investigated for normality using histogram and the results are presented in Figure III below.

Figure III. Histogram of Business Environment

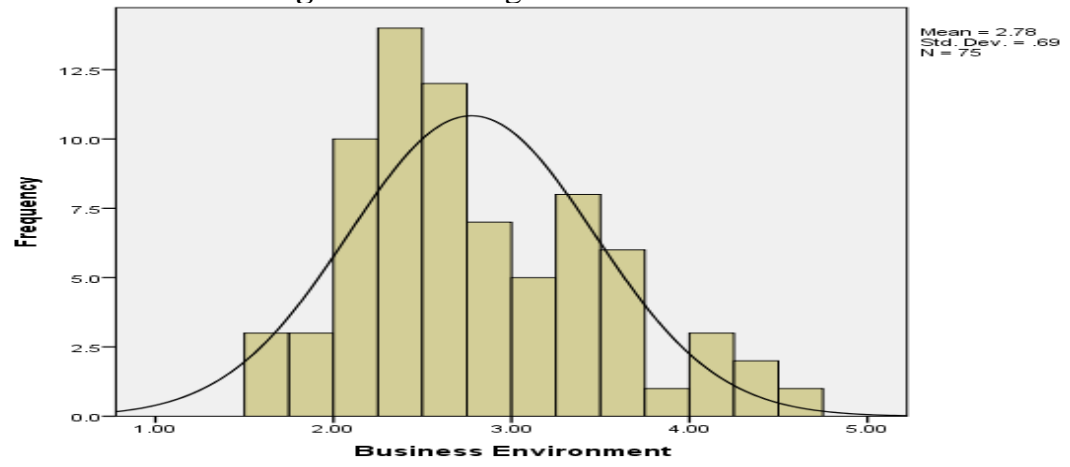

Source: Field Data 2019 
According to Figure III, business environment, as a moderating variable, provided responses after exploring for normality. Thus, the distribution of responses for the variable were normally distributed and the histogram was bell-shaped with a mean equal to $2.78(S D=0.69)$. Therefore, it was concluded that the normality precondition of parametric evaluation was not violated and the data can be subjected to regression analysis.

\section{iii) Manufacturing Performance}

The manufacturing performance variable was investigated for normality using histogram. Figure IV below is a symmetrical histogram indicating that the independent variable Manufacturing Performance was normally distributed. Manufacturing Performance, as a response variable, provided responses after exploring for normality. Thus, the responses for manufacturing performance were normally distributed and the histogram was bell-shaped with a mean equal to $2.77(S D=0.52)$. Therefore, there is evidence to conclude that the data for manufacturing performance did not deviate from normality. The histogram is presented below.

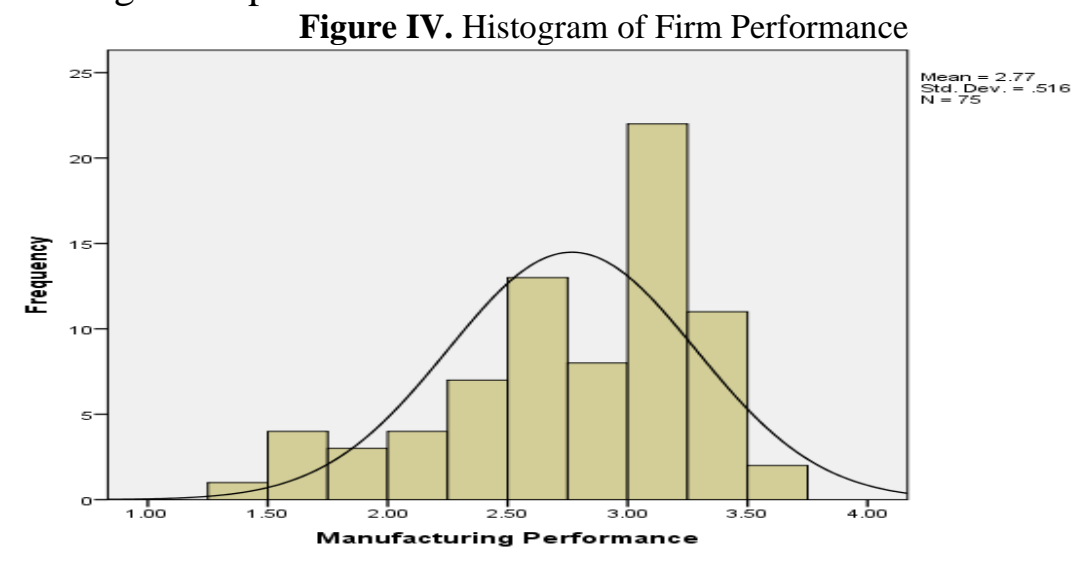

Source: Field Data 2019

\subsubsection{Multicollinearity Test}

Multicollinearity occurs when there are multiple explanatory variables that exhibit high degree of correlations (Mugenda \& Mugenda, 2003; Zientek, Kim \& Amanda, 2016). In order to check for this precondition, the variance inflation factor (VIF) test was invoked. Based on this test, a VIF exceeding 10 indicates multicollinearity (Hair, Anderson, Tatham \& Black, 2008). The results of this test are presented in Table V. 
Table V. Collinearity Statistics

\begin{tabular}{lll}
\hline Variable & \multicolumn{2}{l}{ Collinearity Statistics } \\
& Tolerance & VIF \\
\hline Foreign Direct Investment & .984 & 1.016 \\
Business Environment & .986 & 1.014 \\
\hline
\end{tabular}

Dependent Variable: "Manufacturing Performance

Source: Field Data (2019)

Table V shows that the VIF ranged from 1.012 to 1.016 for the three variables of interest. The values being more than 1 and less than 10 indicate that there was absence of multicollinearity. Additionally, the tolerance values for all the variables ranged from 0.984 to 0.988 . This further confirms nonviolation of the precondition.

\subsubsection{Homogeneity Tests}

Homoscedacity test is done to examine whether the different values of responses have the same variances regardless of the values of the predictor variable. The levene test was used to assess this precondition. This test examines whether or not the null hypothesis which states that there is no equality in the variances of two populations is true (Hair et al., 2008). For the purpose of this study, this test was grounded on a 5\% significance level. The results of the test are shown in Table VI.

Table VI. Levene Test Statistics

\begin{tabular}{lllll}
\hline Variable & Levene Statistic & df1 & df2 & Sig. \\
\hline Foreign Direct Investment & 2.733 & 12 & 58 & .005 \\
Business Environment & 2.487 & 12 & 58 & .011 \\
\hline
\end{tabular}

Source: Field Data (2019)

Table VII shows that out of the three variables, only absorption capacity had a $p$-value greater than 0.05 . Therefore, the null hypothesis that the data for absorption capacity did not fulfil the homoscedasticity condition was rejected. It was also concluded on the basis of the $p$-values that foreign direct investment and business environment did not meet the precondition.

\subsection{Analysis}

The researcher set out to test the effect of business environment on the relationship between FDI and performance of manufacturing firms. The study developed a hypothesis, and it was tested using simple linear regression analysis. The results from the test of the hypothesis are presented in the preceding section. 


\subsubsection{The Moderating Influence of Business Environment on FDI and Performance of Manufacturing Firms}

To prove for the moderating influences of business environment in the link between FDI and firm performance, the following hypothesis was presented:

H03: The business environment does not have a moderating effect on the relationship between FDI and performance of manufacturing firms in Kenya.

The three-step approach of Baron and Kenny (1986) was invoked to draw inferences about the possible moderating influence of business environment. In the first step, FDI was regressed on performance. In the second step, business environment was included in the model as an explanatory variable. Finally, the interaction term between FDI and business environment was added to the model. The moderation effects are presumed if all the model produces significant results with the interaction term. This is illustrated in Figure V.

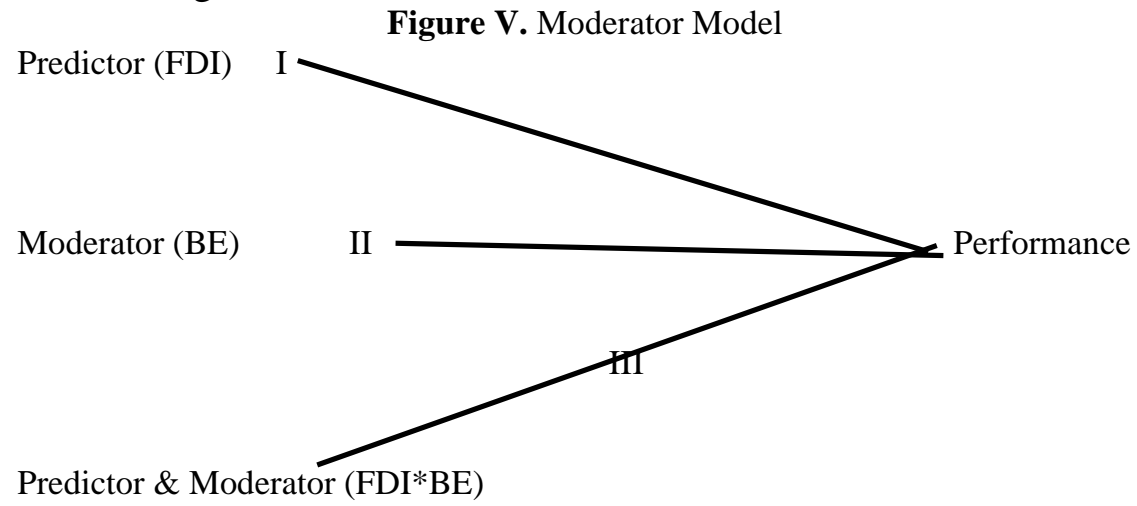

Source: Adapted from Baron and Kenny (1986) model

The results of applying this approach are displayed in Table VII. Here, model one showed $\mathrm{R}^{2}$ of 0.079 while the introduction of the moderator in model three showed a marginal increase of $\mathrm{R}^{2}$ to 0.102 . There was also marginal positive increase in strength of relationship from 0.281 to 0.32 . The results further showed that the model with the interaction term had p-value of 0.05 , which was equal or less than the set p-value of 0.05 . The study therefore rejected the null hypothesis and concluded that business environment had a moderating role in the relationship between FDI and the manufacturing firm performance. The coefficients of moderation are presented in Table VIII. 
Table VII. Moderating Effect of Business Environment

\begin{tabular}{|c|c|c|c|c|c|c|c|c|c|}
\hline \multicolumn{10}{|c|}{ Model Summary } \\
\hline \multirow{2}{*}{ Model } & \multirow[t]{2}{*}{$\mathrm{R}$} & \multirow{2}{*}{\multicolumn{2}{|c|}{\begin{tabular}{|l|l} 
R Square & $\begin{array}{l}\text { Adjusted R } \\
\text { Square }\end{array}$
\end{tabular}}} & \multirow{2}{*}{$\begin{array}{l}\text { Std.Error } \\
\text { of the } \\
\text { Estimate }\end{array}$} & \multicolumn{5}{|c|}{ Change Statistics } \\
\hline & & & & & $\begin{array}{l}\mathrm{R} \text { Square } \\
\text { Change }\end{array}$ & F Change & df1 & df2 & $\begin{array}{l}\text { Sig. } \\
\text { Chang }\end{array}$ \\
\hline $\begin{array}{l}1 \\
2 \\
3\end{array}$ & $\begin{array}{l}.281^{\mathrm{a}} \\
.297^{\mathrm{b}} \\
.320^{\mathrm{c}}\end{array}$ & $\begin{array}{l}.079 \\
.088 \\
.102\end{array}$ & $\begin{array}{l}.067 \\
.063 \\
.064\end{array}$ & $\begin{array}{l}.49882 \\
.49984 \\
.49943\end{array}$ & $\begin{array}{l}.079 \\
.009 \\
.014\end{array}$ & \begin{tabular}{|l}
6.282 \\
.704 \\
1.117
\end{tabular} & $\begin{array}{l}1 \\
1 \\
1\end{array}$ & $\begin{array}{l}73 \\
72 \\
71\end{array}$ & $\begin{array}{l}.014 \\
.404 \\
.294\end{array}$ \\
\hline
\end{tabular}

a. Predictors: (Constant), Foreign Direct Investment

b. Predictors: (Constant), Foreign Direct Investment, Business Environment

c. Predictors: (Constant), Foreign Direct Investment, Business Environment, Moderator

\section{ANOVA $^{\text {a }}$}

\begin{tabular}{|c|c|c|c|c|c|}
\hline Model & Sum of Squares & Df & Mean Square & $\mathrm{F}$ & Sig. \\
\hline Regression & 1.563 & 1 & 1.563 & 6.282 & $.014^{\mathrm{b}}$ \\
\hline 1 Residual & 18.164 & 73 & .249 & & \\
\hline Total & 19.727 & 74 & & & \\
\hline Regression & 1.739 & 2 & .870 & 3.480 & $.036^{\mathrm{c}}$ \\
\hline 2 Residual & 17.988 & 72 & .250 & & \\
\hline Total & 19.727 & 74 & & & \\
\hline Regression & 2.018 & 3 & .673 & 2.697 & $.050^{\mathrm{d}}$ \\
\hline 3 Residual & 17.709 & 71 & .249 & & \\
\hline Total & 19.727 & 74 & & & \\
\hline
\end{tabular}

a. Dependent Variable: Manufacturing Performance

b. Predictors: (Constant), Foreign Direct Investment

c. Predictors: (Constant), Foreign Direct Investment, Business Environment

d. Predictors: (Constant), Foreign Direct Investment, Business Environment, Moderator

Source: Field Data (2019) 
Table VIII. Coefficients of the Interaction between Business Environment and FDI

\begin{tabular}{|c|c|c|c|c|c|}
\hline \multicolumn{6}{|l|}{ Coefficients $^{\mathbf{a}}$} \\
\hline \multirow[t]{2}{*}{ Model } & \multicolumn{2}{|c|}{$\begin{array}{l}\text { Unstandardized } \\
\text { Coefficients }\end{array}$} & Standardized & \multirow[t]{2}{*}{$T$} & \multirow[t]{2}{*}{ Sig. } \\
\hline & $\mathrm{R}$ & Std Frror & Coemcients & & \\
\hline (Constant) & 1.618 & 462 & & 3.500 & .001 \\
\hline 1 Foreign Direct Investment & .467 & .186 & .281 & 2.506 & .014 \\
\hline (Constant) & 1.459 & .501 & & 2.914 & 005 \\
\hline 2 Foreign Direct Investment & .452 & .188 & .272 & 2.408 & .019 \\
\hline Business Environment & .071 & .085 & .095 & .839 & 404 \\
\hline (Constant) & 1.438 & .501 & & 2.873 & 005 \\
\hline Foreign Direct Investment & .432 & .188 & .261 & 2.295 & .025 \\
\hline Business Environment & .098 & .088 & .131 & 1.110 & .271 \\
\hline Moderator & -.070 & .066 & -.124 & -1.057 & .294 \\
\hline
\end{tabular}

Source: Field Data (2019)

As illustrated in Table VIII, Model 1 shows the coefficient of the independent variable and dependent variable. Model 2 shows the independent variable, moderator variable, and dependent variable. Model 3 shows the relationship of the moderator with the interaction term. These relationships are represented in the following equations:

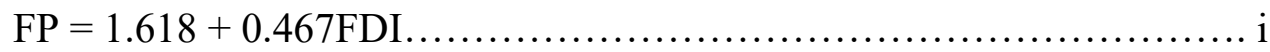

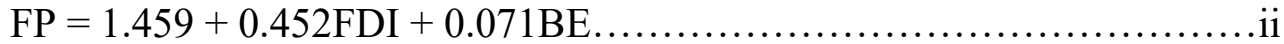

$\mathrm{FP}=1.438+0.432 \mathrm{FDI}+0.098 \mathrm{BE}-0.070 \mathrm{FDI} * \mathrm{BE} \ldots \ldots \ldots \ldots \ldots \ldots \ldots \ldots$ iii

Where: $\mathrm{FP}=$ Firm performance;

FDI $=$ Foreign Direct Investment,

$\mathrm{BE}=$ Business Environment.

In Model 1, a unit change in FDI would lead to $46.7 \%$ increase in performance. In Model 2, a unit change in FDI would yield 45.2\% improvement in performance while a unit change in business environment would produce a $7.1 \%$ increase in performance. In Model 3, a unit change in FDI and business environment would result in 0.432 and 0.098 change in performance, respectively. The results also demonstrate that a unit incremental change in the interaction between FDI and business environment would generate a $7 \%$ growth in performance of the companies.

\subsection{Discussion}

\subsubsection{FDI, Business Environment, and Performance of Manufacturing Firms}

The study also sought to empirically test whether business conditions modified the nature of relationship between FDI and the performance of 
manufacturing companies. The approach used by Baron and Kenny tested the possible moderating role of business environment conditions. The findings for firm performance showed that when the moderating variable was included in the model in step 3, the coefficient of determination for the interaction term was statistically significant (adjusted $\mathrm{R} 2=0.102, \mathrm{~F}=1.117, \beta=-0.098, \mathrm{t}=-$ $3.628, p>0.05$ ). These results were an indication that the moderating effects of business environment were operative in the link between FDI and the performance of the companies. Consequently, the researcher rejected the hypothesis that business environment does not have a moderating effect on the relationship between FDI and the performance of manufacturing firms in Kenya.

The study outcomes are also similar to the findings of Hodud et al. (2014). According to their study, it was established that good business environments improved productivity. Also, increase in the infrastructure efficiency and business regulations support business growth (Hodud et al., 2014). This study also supports the findings of Hallward-Driemeier et al. (2006) that business growth was negatively influenced by the laws passed by a country.

Furthermore, the current study also supports the findings by Edrees (2015) who asserted that countries with well-laid financial market benefited positively from foreign direct investment. More so, there was negative association between FDI and economic development across low-income and middle-income strata using variables such as human resource and infrastructure on the economic performance of SSA countries. The research further supports the findings by Pradhan and Bagchi (2013) who posited that investment into the transport systems minimizes trading costs and consequently improves the competitive advantage of firms. The study also agrees with Alfao, Chanda, Oscan, and Sayek's (cited in Muhammad and Kashif, 2013) who established that foreign direct investment promoted growth about three times in countries that had well-developed financial systems than their counterparts with poor financial systems.

However, the current study was inconsistent with some earlier researchers like Ayyagair et al. (2006) that found no link between the performance of companies and the regulations enforced by the government. The inconsistencies among the results of this research and the previous researches could be attributed to differences in conceptualization and measures of the business environment. However, the research adds to the extant literature on business environment and the performance of firms. Consequently, this study offers a framework that provides a better understanding of how business environment moderates the association between FDI and firm performance. The findings suggest the need to attract FDI and improve business environment (financial constraints, government 
regulations and physical infrastructure), which in turn influences firm's performance.

\section{Conclusion}

The objective of the research was to determine whether business environment had moderating implications on the link between FDI and performance. Business environment was operationalized as financial access, government regulations, and physical infrastructure. The results indicated that business environment had a statistically significant moderating effect in the relationship between FDI and the performance of manufacturing firms in Kenya. Consequently, the hypothesis that business environment does not have a moderating effect on the relationship between FDI and the performance of Manufacturing firms in Kenya was rejected. Based on the above findings, it can be deduced that business environment moderates the relationship between FDI and firm performances.

This study contributes to the growing body of literature on the role of business environment in the relationship between FDI and firm performance. The policy makers of Kenya and Sub-Sahara African countries are informed by the findings of this study that business environment is an important ingredient in enabling the spillovers from foreign to local firms. Therefore, it is important to continue improving the local business environment to facilitate this spillover.

\section{Acknowledgements}

We wish to profoundly acknowledge the organizations that made the access of data possible, namely: the Kenya Association of Manufacturer and Kenya Export Promotion Center. In this regard, a special appreciation goes to the many manufacturing firms that participated in the study. We thank you all!

\section{References:}

1. Baron, R. M. \& Kenny, D. A. (1986). The moderator-mediator variable distinction in social psychological research: Conceptual, strategic, and statistical considerations. Journal of Personality and Social Psychology, 51, pg. 1173-1182.

2. Brașoveanu, I.V. \& EvelinaBălu, P. (2014). The Influence of the Business Environment on Small and Medium Enterprises. Journal of Knowledge Management, Economics and Information Technology, Vol. iv, Issue 2.

3. Bruno, R. L. \& Cipollina, M., (2014), FDI impact on Firm Performance in Enlarged Europe: Evidence from a Meta-Regression Analysis, IZA Discussion Paper No. 8085. 
4. Cabrita, R. \& Bontis, N. (2008). Intellectual capital \& business performance in Portuguese banking industry. International Journal of Technology Management, Vol.43, pp.212-237.

5. Dethier, J., Hirn, M., \& Straub, S. (2010). Explaining enterprise performance in developing countries with business climate survey data, The World Bank research observer, 26, pp.258-309.

6. Edrees, A. (2015). Foreign Direct Investment, Business Environment and Economic Growth in Sub Saharan Africa: Pooled Mean Group Technique, Journal of Global Economics, Volume 3, Issue 2.

7. Gui-Diby, S.L. (2014). Impact of foreign direct investments on economic growth in Africa: Evidence from three decades of panel data analyses. Research in Economics, 68: pp 248-256.

8. Hair, J. F., Anderson, R. E., Tatham, R. L., \& Black, W.C. (2008). Multivariate data analysis, 5th Edition, Upper Sadddle River: NJ, Prentice Hall

9. Hodud, E., Madline, B., Faridah, B., Shamshubarida, S, B. R., \& Mohd, F. B. M. (2014). The impact of business environment on firm's employment growth, Global Journal of Management \& Business research, Economics and Commerce, Vol 14, Issues 8.

10. Hsiang-Feng, T., Hsien-Bin, W., \& Dja-Shin, W. (2012). The moderating role of enviro mental dynamism on the influence of innovation strategy and firm performance, International Journal of Innovation, Management and Technology, Vol. 3, No. 5.

11. Kamran, B., Chor, D., \& Manova, K. (2016). "Host Country Financial Development and Mult national Activity", GPN Working Paper Series \# GPN2016-011.

12. Kenya Association of Manufacturers (2018). Manufacturing in Kenya Under the 'Big 4 Agenda' A Sector Deep-dive Report. Publication of Kenya Association of Manufacturers, Kenya.

13. Kenya National Bureau of Statistics, Central Bank of Kenya, KenInvest (2016). Foreign Direct Investment survey report.

14. Khondoker, A. M. \& Kaliappa, K., (2010), Determinants of Foreign Direct Investment in Developing Countries: A Comparative Analysis; ASARC Working Paper 2010/13

15. Kombo, D. K. \& Tromp, L. A. (2009). Proposal and thesis writing: An introduction. Nairobi: Paulines publications Africa.

16. Kothari, C. R. (2014). Research Methodology: Methods and Techniques. New Delhi, India: New Age International Publishers. Second revised edition

17. Leman, E. \& Ismet, G. (2015). The Effects of Foreign Direct Investment on R\&D and Innovations: Panel Data Analysis for Developing Asian Countries. World Conference on Technology, 
Innovation and Entrepreneurship. Procedia-Social and Behavioral Sciences 195, pp.749-758. Online at www.sciencedirect.com

18. Miot, H.A. (2017). Assessing Normality of Data in Clinical and Experimental Trials. Journal Vascular Brasileiro , 16(2).

19. Mugenda, O. M. \& Mugenda, A. G. (2003). Research Methods. Quantitative and Qualitative Approaches. Nairobi: African Centre for Technology Studies Press.

20. Muhammad, T. M. \& Kashif, R. (2013). Does Foreign Direct Investment Influence Economic Growth and Human Capital of Host Countries? A Review of Empirical Evidence. World Applied Sciences Journal. 21 (8), 1116-1121

21. Okeyo, W.O. (2013). Entrepreneurial Orientation, Business Environment, Business Development services and performance of small and medium Manufacturing firms in Kenya, Unpublished $\mathrm{PhD}$ Thesis, U.O.N

22. Onyekwena, C. (2012), Empirical investigation of the impact of Foreign Direct Investment on manufacturing firms and banks in Nigeria, Unpublished PhD Thesis, University of Portsmouth

23. Pallant, J. (2005). SPSS Survival Manual: A Step by Step Guide to Data Analysis Using SPSS for Windows (V.12).

24. Pradhan, R.P. \& Bagchi, T.P. (2013). Effect of transportation infrastructure on economic growth in India: The VECM approach. Research in Transportation Economics 38:139-148.

25. Shabarati, A., Jawad, J., \& Bontis, N. (2010). Intellectual capital and business performance in pharmaceutical sector of Jordan. Management Decision Journal, 48 (1), 105-13.

26. Sprenger, C. \& Lazarevaa, O. (2016). Corporate Governance and Investment: Evidence from Russian Unlisted Firms. Available at https://www.aeaweb.org/conference/2017/ preliminary/paper/nNf2KArF

27. World Bank (2017). Business Environment and Firm Performance in European Lagging Regions Policy Research, Working Paper 8281. Available Web at http://econ.worldbank.org

28. Zientek, L.R., Kim, N., \& Amanda, K. (2016). All Possible Subjects for MANOVA and Factorial MANOVAs: Less than a Weekend Project. International Journal of Adult Vocational education and technology, 7 (2). 